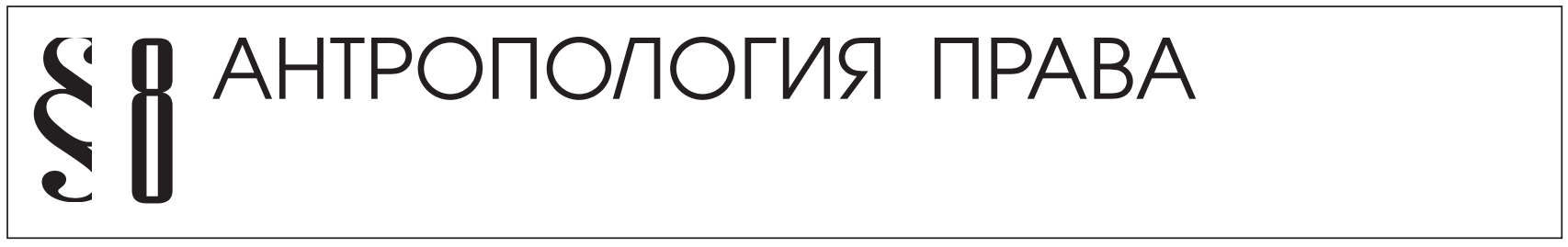

Кочетков В.В.

\title{
СРАВНИТЕЛЬНЫЙ АНАЛИЗ ОСНОВНЫХ ЗАКОНОВ РОССИЙСКОЙ ИМПЕРИИ 1906 ГОДА И КОНСТИТУЦИИ РФ 1993 ГОДА: К ИСТОРИИ КОНСТИТУЦИОНАЛИЗАЦИИ РУССКОЙ ВЛАСТИ
}

\begin{abstract}
Аннотация: В статье анализируется исходные цели и результаты двух попыток конституционализации русской власти, предпринятых в 1906 и 1993 годах. На основе текстов этих Основных законов и правовой доктрины соответствующего времени показывается, что рецепция некоторых конституционных институтов не привела $\kappa$ имплементации конституционных ценностей и принципов в ткань государственной и общественной жизни. Причина этого, по мнению автора, заключается в том, что архетипы русской власти - самодержавие главы государства и дистинкиия верховного и подчиненного управления - не позволяют осуществить её конституционализачию, что и приводит кмнимому конституционализму. Основным методом исследования в настоящей статье был выбран метод единства исторического и логического в сочетании традиционным юридико-догматическим методом анализа правовых документов. Новизной данного исследования является сама постановка вопроса об архетипов русской власти на примере анализа конституиионных текстов разных периодов российской истории. На основе этого автор приходит к следующему выводу. Для того чтобы конституционализация русской власти стала возможна, необходимо, основываясь на аксиологическом понимании конституционализма, предложенного автором, преодолеть её архетипы и последовательно имплементировать конституционные иенности 6 российское государственное право.
\end{abstract}

Ключевые слова: Конституционализация, правосознание, архетип власти, Основные законы империи, Конституция Российской Федерации, рецепиия, права человека, свобода, разделение властей, конституционные ценности.

Abstract: This article analyzes the original goals and results of the two attempts of constitutionalization of Russia undertaken in 1906 and 1993. Based on these fundamental laws and legal doctrine of the corresponding period, the author demonstrates that the reception of certain constitutional institutions did not result in implementation of constitutional values and principles into the fabric of the state and public life. In author's opinion, the cause for this lies in the fact that the architypes of Russian authority - the autocracy of the head of state and distinction between the executive and subordinate administration - do not allow to constitutionalize it, which results in only an ostensible constitutionalism. The scientific novelty of this research is the very statement of the question of architypes of Russian authority on the example of analysis of the constitutional texts from the various periods of Russian history. The author comes to the conclusion that in order for constitutionalization of the Russian authority to become possible, it is necessary (based on the axiological understanding of constitutionalism proposed by the author) to overcome its architypes and sequentially implement constitutional values into the Russian state law.

Keywords: Reception, Constitution of the Russian Federation, Fundamental laws of the Russian Empire, archetype of power, legal consciousness, constitutionalization, human rights, freedom, seperation of powers, constitional values.

уть от несвободы к свободе тернист и долог. И это связано не только с силой общественных классов, заинтересованных в сохранении старого порядка. Но и с тем, что та или иная форма зависимости отдельного индивида, например, личная (от семьи, рода или племени) или потребность в защите (от более сильного, от враждебной природной или социальной среды), является органичной и естественной для человеческого общества с исторической точки зрения. И на протяжении всей человеческой истории, как правило, свобода немногих всегда была верхушкой пирамиды несвободы большинства. Устоявшиеся формы таких 
зависимостей (правосознание и правоприменение) мы и называем архетипами власти.

Только в эпоху Модерна возникли две теоретические парадигмы, которые объясняли эту «естественную» социальную ситуацию и предлагали пути её изменения. Первая (её впоследствии назвали конституционализмом) парадигма исходила из того, что развитие человеческого разума позволяет через признание естественных, политических, социальных и культурных прав за каждым человеком построить такой государственный строй, при котором каждый мог бы свободно и не в ущерб другим реализовывать свою концепцию благой (правильной и субъективно желаемой) жизни. Признание за каждым права на частную и публичную автономию требовало конституциионализации власти и её архетипов. Вторая парадигма (на практике реализовывалась национал-социалистами и коммунистами) исходила из несовершенства человеческой природы и поэтому считала необходимым элиминировать свободу немногих и через равенство в несвободе каждого реализовать идеал органического общества в виде своеобразного человеческого улья, где индивидуальное счастье состоит в реализации своих обязанностей на благо самоценного целого (партии, нации, расы). К концу ХХ века стало очевидно, что конституционализм как система внутренне связанных между собой ценностей и правовых норм позволяет достичь более высокого уровня развития личности и общества. Хотя это понимание и далось ценой того, что две высокоразвитые в культурном смысле страны Европы - Россия и Германия - в течение последнего столетия отказались от конституционализма и стали полигонами для тоталитарных практик.

В истории известны две попытки осуществить конституционализацию русской власти. Первая случилась в результате революции 1905 года и была оформлена с принятием Основных законов Российской империи 1906 года. Однако, как мы покажем ниже, архетипы русской власти серьезно исказили аксиологический смысл этой конституции, что и привело, в конечном счете, к катастрофе 1917 года. Вторая попытка была осуществлена в 1993 году с принятием Конституции Российской Федерации. Однако и современная Россия, возникшая на обломках Советского Союза, также все двадцать лет своей истории балансирует между свободой и несвободой, а у большинства населения страны создается впечатление, что свобода ведет к хаосу и распаду государства. Представляется, что сравнительный анализ этих попыток через призму архетипов русской власти позволит наметить надежные пути имплементации конституционных принципов в ткань российского бытия.

В данной работе под конституциионализмом понимается особая публично-правовая этика (форма правосознания), а также дедуцируемая из её исходных ценностей (архетипов) реальная политическая практика, которая считает возможным и необходимым строить на рациональной основе систему государственного управления, то есть порядок взаимоотношений между гражданином и властью, между гражданами, а также между суверенными государствами. Эта форма правосознания исходит из признания равного достоинства за каждым свободно определяющимся (суверенным) субъектом социума (индивид, группа граждан, нация) или международного сообщества (государство). Данное признание достоинства реализуется через предикацию естественных и неотчуждаемых (что есть гарантия свободы разума и воли в рамках правил поведения данного общества) прав (свободы делать/ не делать что-либо) гражданина (объединений граждан, наций, государств) при условии признания последним (последними) и честного следования всей совокупности рациональных правил общественной, государственной и межгосударственной жизни. Иначе говоря, конституционализм есть некая теоретическая парадигма правосознания, решающиая задачу по разработке определенньх принципов справедливого устройства общественной жизни, которые позволяют обеспечить реализацию частной и публичной автономии для всех сочиальных субъектов. Также можно сказать, что она есть определенный способ рационализации правовых чувств (базовых ценностей) народа. Для него категории «свободы», «справедливости» и «человеческого достоинства» являются взаимосвязанными фундаментальными ценностями.

В этой связи необходимо подчеркнуть, что конституция как политико-философский документ высшей юридической силы без конституционализма как определенной формы правосознания (картины мира) превращается, как правило, в фиговый листок правящего меньшинства, доминирующего над большинством. В этом случае властвующая элита через принятие конституции просто легитимирует свое господство перед мировым сообществом, подобно тому, как на заре становления европейских государств каждый племенной вождь варваров мечтал получить королевскую корону из рук Папы римского. В современном мире наличие конституции также есть признак суверенности правительства и, следовательно, признания его другими правителями как легитимного и равного. Но наличие 
DOI: $10.7256 / 1811-9018.2015 .9 .14210$

При цитировании этой статьи сноска на доі обязательна

\section{Право и политика 9 (189) • 2015}

конституции, к сожалению, не свидетельствует о суверенности народа, о признании достоинства каждого человека через реальное гарантирование ему прав и свобод. Это также не свидетельствует о наличии в этой стране конституционализма как определенной формы правосознания.

Конституционное правосознание вступает в свои права, когда на повестку общественной жизни встает конституционный вопрос, который можно определить как когнитивный диссонанс между рационально выраженными ценностями свободы, справедливости и человеческого достоинства и отсутствием реальных условий для их реализации на практике. Конституциионый вопрос взаимосвязывает отсутствие возможностей для реализации права на частную и публичную автономию с особенностями наличных властных институтов, и тем самым подрывает легитимность существующего политического и правового порядка. В зависимости от способов решения конституционного вопроса, от уровня рационализации и имплементации ценностей конституционализма в государственном праве и политической практике, можно выделить подлинный и мнимый конституционализм, а также его различные национальные формы. Иными словами, различая подлинный или мнимый конституционализм, мы рассматриваем вопрос об имплентации основных архетипов конституционного правосознания (свобода, справедливость, достоинство, народный суверенитет, др.) в систему государственного права конкретной страны. Говоря о той или иной национальной форме конституционализма, мы анализируем процесс рецепции конституционных публично-правовых институтов в конкретной системе государственного права и об особенностях рационализации архетипов конституционного правосознания в правовой доктрине. Конечно, конституционализм как международное политико-правовое и культурное явление гораздо шире своей нормативной основы и конституционного права. Но у всех народов, избравших конституционализм в качестве доктрины государственного строительства, политические институты отвечают следующим требованиям:

- $\quad$ обеспечение защиты основных прав человека и гражданина;

- $\quad$ верховенство права и ограничение сферы дискреции государственной власти;

- $\quad$ формальное равенство всех перед законом;

- разделение государственной власти;

- $\quad$ осуществление законодательной власти органом народного представительства;
- $\quad$ ответственность исполнительной власти перед высшим законодательным органом народного представительства.

Рассмотрим, как можно применить наши исходные теоретические положения при анализе постановки и решения конституционного вопроса в Российской империи в начале XX века, когда на фоне неудач в японо-русской войне в 1904 г. начался кризис легитимности самодержавия. Основными конституционными идеями того времени являлись: ограничение самодержавия и введение представительного правления, провозглашение политических и гражданских прав и свобод подданных, утверждение верховенства права и законности, а также всеобщего избирательного права, то есть установление реальной демократии в конституционной монархии. Российские конституционалисты предприняли попытку осмыслить и обосновать эти идеи в теории «конституционного государства». Под таковым они понимали такое государственное устройство, при котором народные представители, избранные в двухпалатный парламент, имеют исключительное право издавать законы, контролировать через разнообразные правовые механизмы исполнительную власть и поддерживать независимость суда, который только и может обеспечить реальную защиту прав и свобод граждан. Но при этом ведущим элементом данного понятия было наличие парламента. Например, по мнению B.M. Гессена, «господство законодательной власти в конституционном государстве является следствием её представительского характера. Закон, как выражение общей воли, господствует над «частными» волями органов государственной власти». [1] Верховенство права сводилось ими к подчинению исполнительной власти закону, понимаемому в формальном смысле как нормативный акт, принятый органом народного представительства. В силу этого российские конституционалисты начала XX века признали за конституцию мнимый конституционализм Основных законов 1906 года, и тем самыми они лишились возможности по существу разработать ему теоретическую альтернативу и донести это до граждан. В итоге, как известно, российский народ в октябре 1917 г. отверг Основные законы 1906 г. вместе с конституционным путем развития страны.

Они также считали, что конституционное государство возникает естественноисторическим путем. И что задачей науки конституционного права является объяснение этой необходимости неразумным представителям элиты и народа. Как отмечал в этой связи С.А. Корф: «Общераспространенность факта возникновения конституционной формы государ- 
ственного строя ясно свидетельствует, что таковая не есть какое-либо местное или случайное явление, а особая стадия развития государственности, обусловливаемая некоторыми также общераспространенными социальными факторами; во всех государствах, достигающих известную ступень культуры, под влиянием растущего народного образования национального самосознания, наступает момент, когда народ проявляет стремление, в той или другой форме, участвовать в осуществлении функций государственной власти, чаще всего в законодательстве. Внутренним стимулом этого фактора повсюду бывала неудовлетворенность личного статуса гражданина в государстве, другими словами, необеспеченность его личных прав от посягательств всемогущей государственной власти». [2] Иначе говоря, несмотря на исторические факты, говорящие о длительности процесса рецепции конституционных институтов в различных странах, российские конституционалисты начала XX века в общем и целом были почему-то убеждены в том, что в России этот процесс будет скоротечен и успешен.

Однако если использовать метод рассмотрения феномена конституционализма в единстве исторического и логического аспектов, то мы получим другую картину. С точки зрения истории, конституционное государство является продуктом естественного развития англосаксонских народов, достигшим своей вершины в Конституции США 1787 года и Билле о правах 1791 года. Именно Британия в XVIII веке и США в XIX веке стали образцом для подражания и предметом осмысления для ведущих интеллектуалов в других странах. Иначе говоря, с исторической точки зрения, конституционное государство сначала сформировалось в Англии, а потом рационализировалось (осмыслялось и анализировалось) в США. Успехи этих стран в международной конкуренции, а также череда буржуазных революций в XIX веке показали неэффективность государств Старого режима и подвигли их элиты на реформирование через конституционализацию своей власти.

С логической точки зрения предпосылки теории конституционализма необходимо искать в принципах английского общего права (common law), которые исходят при разрешении правового спора из предпосылки существования стоящей над любой властью справедливости, а также из частноправовой теории собственности. Как известно, в сфере гражданского оборота лицо имеет абсолютную свободу, то есть власть над вещью. Вдумчивый читатель может возраз- ить, что институт частной собственности как jus utendi et abutendi был детально еще разработан в древнеримском частном праве, однако он оказался вполне совместим с неограниченным произволом императорской власти, и, следовательно, сам по себе этот институт ничего не гарантирует и не обеспечивает. Отличие же английского общего права в том и состоит, что правосубъектность личности не редуцируется к частной собственности, а основывается на её частной и публичной автономии, подкрепленной справедливостью независимого правосудия, в котором участвуют равные социальные субъекты. С развитием товароденежных отношений с XII века в Англии принципы гражданского оборота стали всеобщими, а значит индивид, имеющий власть над вещами (деньгами), необходимыми для монарха, перестает быть только объектом для власти. Он стремится распространить принцип равенства сторон из гражданского оборота на сферу публично-властных отношений. Сначала он просто откупается от власти, и так появляются личные права. Затем он за свой вклад в виде налогов получает право влиять на власть - так появляются первые парламенты и гражданские (политические) права, основанные на имущественных цензах. И только социальная борьба, проходящая красной нитью через XIX - XX столетия, распространила эти и другие права на весь остальной народ (сначала на мужчин, достигших определенного возраста, а затем и на женщин).

Выдвигая тезис о народном суверенитете и о народном правосознании как источнике законотворчества в конституционном государстве вообще, российские ученые того времени полностью игнорировали тот факт, что правосознание конкретного российского народа не принимало малопонятные ему конструкции конституционного права. Что и привело российских конституционалистов начала XX века к отрыву от интересов крестьянства по вопросу о земле, от интересов рабочих по вопросу о социальных правах, от интересов национальных меньшинств по вопросу о федерализации российской империи. Как мы помним, свои ответы на эти запросы дали левые эсеры и большевики в октябре 1917 года, но эти ответы радикально отличались от теории конституционализма.

Справедливо различая конституционное и правовое государства, они исповедовали, исходя из приоритета законодательной власти и формального определения закона, принцип верховенства законов. Хотя в форму закона, как известно, может быть облачен и произвол. Игнорируя различия между законом как рационализированной волей государственной власти, и правом, как 
DOI: $10.7256 / 1811-9018.2015 .9 .14210$

При цитировании этой статьи сноска на доі обязательна

\section{Право и политика 9 (189) 2015}

рационализированной справедливости, они лишали себя критерия отделения правового закона от неправового нормативного акта. Теоретически эту коллизию мог бы разрешать, по примеру США, некий Верховный суд на основе толкования норм и духа конституции. Но этот вопрос детально не был проработан в их теориях. А как быть в условиях мнимого конституционализма, где искать право для оценки таких законов, они этим вопросом в силу вышеуказанных ограничений вообще не озадачивались.

И последнее, но не по значению. Сводя все учение конституционализма к теории конституционного государства, они существенно обедняли данную парадигму. Справедливо полагая, что защита прав и свобод граждан есть имманентная цель конституционного государства, они игнорировали, что признание ценности прав человека должна произойти и самими гражданами, и представителями властвующей элиты. Как справедливо заметил Б. А. Кистяковский: «Правовые идеи нельзя просто «заимствовать», в сознании каждого народа они получают своеобразную окраску и свой собственный оттенок». [3] По его мнению, обе стороны этого идеала личность, дисциплинированная правом, и личность, наделенной правами и свободно пользующейся ими, были одинаково чужды правосознанию российского народа и элиты. А ведь вполне очевидно, что без стремления честно следовать правилам общежития в конституционном государстве всеми и, прежде всего, представителями элиты, любые, даже самые замечательные и теоретически проработанные юридические институты конституционного государства будут мертвы. И даже хуже того, они будут подрывать легитимность такого государства, что будет способствовать приходу к власти самых радикальных противников свободы.

Если обратиться к анализу текста Основных законов 1906 года, то можно сделать вывод, что первая российская конституция по сути дела имитировала введение в государственную жизнь основных принципов конституционализма. По признанию одного теоретика самодержавного правосознания, «реформы 1905 - 1906 гг. не изменили известных основ государственной власти, они установили иной порядок ее волеизъявления». [4] Ведь согласно правовой доктрине того времени, архетипами системы русской власти являлись самодержавие главы государства и дистинкция верховного и подчиненного управления. Проверим, что изменилось с принятием Основных законов 1906 года с точки зрения конституционного правосознания и архетипов русской власти. Так, вместо двухпалатного законодательного органа народного представительства были созданы два равно- правных законодательных собрания - Государственный Совет и Государственная Дума, с весьма ограниченными полномочиями в сфере законотворчества. По справедливой оценке А.Н. Захарова, «реформы законодательных органов, в смысле привлечения к работе выборных от населения и установление формального понятия закона, явились основой нынешних перемен в нашем государственном строе. Отныне понятие закона, понятие формальное, стало точно установленным, и признаками такового является определение внутреннего содержания закона двусторонним соглашением Государственной Думы - палаты народных интересов, и Государственного Совета - палаты государственного опыта и утверждение такого законопроекта Государем Императором». [5] При этом, по сути дела, законодательная инициатива была в руках исполнительной власти. К тому же депутаты Государственной Думы и члены Государственного Совета имели очень незначительные полномочия в области контроля над исполнительной властью. Бюджетный процесс был построен таким образом, что народные представители не имели возможности реально влиять на формирование и распределение бюджета, а в области контроля над его исполнением они по сути дела всего лишь утверждали фактически произведенные государственные расходы. Не было также предусмотрено в «первой российской конституции» никаких механизмов привлечения к ответственности министров, да и сами депутаты имели весьма ограниченную неприкосновенность.

Кроме того, важнейший архетип русской системы власти - неограниченное самодержавие главы государства также был сохранен и конкретизирован в первой русской конституции. В этой связи П.Е. Казанский был даже убежден в том, что «нельзя усмотреть никакого различия между формулами императорской власти в старых Основных законах [1892 года - В.В.К.] и в законах новых [1906 года - B.B.K.]. Как те, так и другие постановляют, что Государю Императору принадлежит полнота государственной власти». [6]

То же самое можно сказать и о дистинкции верховного и подчиненного управления. В своё время Н.М. Коркунов обосновывал её значение следующим образом: «Различие верховного и подчиненного управления имеет совершенно общее значение для всех государств, независимо от различия их устройства. В каждом государстве, будет ли это монархия или республика, властвование проявляется не только в исполнении существующих законов, но также в издании новых законов, в отмене старых и в разрешении вопросов, не определенных наперед законом. Это свободное, не 
DOI: $10.7256 / 1811-9018.2015 .9 .14210$

При цитировании этой статьи сноска на dоі обязательна

Антропология права

определенное в своем содержании раньше изданными законами осуществление властвования обусловлено не особенностью органов власти, а особенностью целей властвования и потому не зависит от или другой формы правления». [7] Из приведенного отрывка четко видно следующее. Если конституционализм видит своей задачей рациональную организацию государственной жизни на основе законов, создаваемых самим народом в лице своих представителей, и, следовательно, отклонение от закона или необходимость управления при пробелах закона, носит исключительный (или чрезвычайный характер), то для архетипов русской власти, несмотря на декларируемую приверженность к управлению государством на основе законов, характерно отсутствие стремления рационализировать (нормировать) способы властвования, и, следовательно, исключительность (чрезвычайность) управления носит постоянный характер.

Точное понимание архетипа «верховного управления» с точки зрения самодержавного правосознания мы можем найти у того же Н.М. Коркунова, который писал: «Компетенция верховного управления не определяется какими-либо положительными началами, а только, так сказать, отрицательно. И для верховного управления обязательны законодательные постановления. И верховное управление не имеет права вторгаться в разрешение дел, подлежащих ведению судебной власти. Но за этими двумя ограничениями деятельность верховного управления совершенно свободна. Ему предоставляется не заведование отдельными, наперед определенными, задачами государственной жизни, а дается общее полномочие управления государством». [8] Именно поэтому в ходе реализации Основных законов 1906 г. их положения часто нарушались монархом и правительством. Права и свободы, закрепленные в их нормах, но не обеспеченные специальным законодательством, регулировались «временными правилами». Это объяснялось тем, что «понятие конституции не влечет за собой отмену самодержавной власти, а лишь определяет ее сущность. С одной стороны, ее можно понимать, как основное свойство нашей Верховной объединенной государственной власти, а с другой, как власть непосредственного волеизъявления, установленную в общих своих чертах в основных законах и непосредственную в этой сфере применения, или вовсе не упоминаемую, но могущую проявить себя в экстраординарную минуту жизни государства». [9]

Далее. Не смотря на то, что принцип разделения властей был формально проведен в Основных законах 1906 года, фактически за народным представительством император и его окружение не признавали никакого самостоятельного значения. А.Н. Захаров обосновывал это следующим образом: «Наша конституция ограничила, прежде всего, само понятие закона, но не свободное волеизъявление Верховной власти, как в области законодательства, так и в иных областях властвования. Вместе с тем не следует упускать из вида, что законодательные палаты определяют лишь содержание закона, но вовсе не законодательствуют». [10] Силу закону придавал император. Кроме того, как гласила ст.10 Основных законов 1906 г.: «Власть управления во всем ее объеме принадлежит Государю Императору в пределах всего государства Российского. В управлении Верховном власть Его действует непосредственно; в делах же управления подчиненного определенная степень власти вверяется от него, согласно закону, подлежащим местам и лицам, действующим Его именем и по Его повелениям».

Как полагали теоретики русской власти того времени, «по общему смыслу нашей конституции, по ее характеру октроирования, следует заключить, что все власти покоятся в особе императора и находят себе выражение в делегировании их известным учреждениям». [11] А, как известно, тот, кто делегирует, может и корректировать. Поэтому в случае малейшего неповиновения Государственная Дума распускалась, одновременно изменялось по Указу Государя избирательное законодательство. Оправдывалось это тем, что самодержец обладает правом верховного управления, которое реализует непосредственно. Так происходило до тех пор, пока российской властвующей элите того времени не удалось сформировать послушную и управляемую Государственную Думу, правда, к этому моменту дни самодержавия были уже сочтены.

Мнимый конституционализм проявлялся не только в сфере законодательства, когда законодательная инициатива была у Государя и его министров, а некоторые сферы правового регулирования - строение армии и флота, чрезвычайное положение - были изъяты из компетенции органа народного представительства, но и в сфере государственного управления (отсутствие механизмов ответственности исполнительной власти перед законодательной властью, возможность управления страной на основе чрезвычайных указов, неконтролируемость бюджетного процесса). Также было и в сфере судебной защиты: отсутствие механизмов судебной защиты субъективных публичных прав граждан, распространение практики придания гражданских лиц военному суду.

В этой связи представляет интерес отношение представителей самодержавного правосознания к одно- 
DOI: $10.7256 / 1811-9018.2015 .9 .14210$

При цитировании этой статьи сноска на доі обязательна

\section{Право и политика 9 (189) • 2015}

временному роспуску второй Государственной Думы и изменением избирательного закона от 3 июня 1907 года. Они были согласны с тем, что это своеобразный разрыв в праве, но исходили из того, что правовыми средствами кризис во взаимоотношениях Думы и правительства нельзя было разрешить. Как писал А.Н. Захаров по этому поводу, «если юридически такой взгляд и последователен, то юридически же не было способов иного разрешения вопроса, и тут применение власти самодержавной не есть осуществление стереотипных норм закона, ее действия и ее сила и заключаются именно в том, что она действовала тогда, когда нормы закона оказались бессильны и попадали в circulus vitiosus». [12] Возникает правомерный вопрос: кто может указать на неправомерность действий правительства и самодержавного монарха? Только Государственная Дума, но новая Дума уже избиралась по неправомерному закону. В этом заключается та сила факта, которая может служить известным основанием для создания правоотношений. Иначе говоря, самодержавие как верховная власть в этом и проявляется - в волевом установлении желательных ему фактов и в устранении фактов для него нежелательных.

Таким образом, архетипы русской власти способствовали тому, что российская правящая элита начала XX века считала возможным игнорировать имплементацию архетипов конституционного правосознания и ограничиваться рецепцией некоторых конституционных институтов, что приводило к потере властью всякой легитимности в глазах общества. Один из идейных монархистов того времени А.И. Гучков так описывал сложившуюся к началу 1917 г. ситуацию: «Историческая драма, которую мы сейчас переживаем, заключается в том, что мы вынуждены отстаивать монархию против монарха, церковь против церковной иерархии, армию против её вождей, авторитет правительственной власти от носителей этой власти». [13] Именно практика мнимого конституционализма привела Российскую империю к краху 1917 года, а теория конституционного государства в том виде, как её разрабатывали ведущие юристы, не позволила разрешить конституционный вопрос того времени.

Подобная ситуация сложилась и в нашей стране с имплементацией принципов конституционализма в политические и правовые институты после принятия в 1993 году Конституции, которая на первый взгляд соответствует самым жестким критериям либеральности и демократичности. Однако, по мнению В.В. Лапаевой, «специфика нынешнего исторического момента заключается в том, что официальная правовая доктрина, получившая закрепление в Конституции РФ, оказалась гуманистичнее все еще доминирующего в российской юриспруденции (как в теории, так и на практике) легистского правопонимания, доставшегося ей в наследство от советского периода». [14] По нашему мнению, причины того, что, по меткому замечанию академика О.Е. Кутафина, мы имеем в нашей стране так называемый «мнимый конституционализм» [15] вместо свободы и демократии, на верность которым присягают российская власть и правоведы, следует искать именно в архетипах русской власти - самодержавии главы государства и дистинкции верховного и подчиненного управления. Более того, именно они имплицитно содержатся в формулах Конституции 1993 года, хотя главы 1 и 2 закрепляют в качестве основы конституционного строя базовые конституционные архетипы, такие как приоритет прав человека, народный суверенитет, демократия, разделения властей. Однако детальный механизм функционирования российской демократической федеративной республики описывается в главе 3 «Федеративное устройство», главе 4 «Президент Российской Федерации», главе 5 «Федеральное Собрание», главе 6 «Правительство» и главе 7 «Судебная власть». И, как показала практика, именно нечеткие или вообще отсутствующие содержательные определения конституционных ценностей (архетипов) создали для российской властвующей элиты возможности для искажения данных принципов в угоду своим корыстным интересам. Так, например, принцип правового государства и верховенства закона был переформулирован в принцип «вертикали власти», что также нарушило и принцип федерализма. Концепция «суверенной демократии» полностью выхолостила политическое многообразие и деформировала принцип разделения властей. Причем такие «творческие» интерпретации основ конституционного строя были поддержаны Конституционным Судом РФ, который свои решения основывал больше на буквальном толковании текста Основного закона, типа, раз прямо не указано в Конституции, то можно все, что представляется власть предержащим целесообразным.

Проиллюстрируем данную ситуацию анализом ст.1, ст.10, ст.11 Конституции в их логической связи со статьями $80-93,94-109,110-117$ и $118-129$, в которых описываются принципы организации исполнительной, законодательной и судебной властей в Российской Федерации. Иначе говоря, посмотрим, как реализуется принцип разделения властей в нашей республике.

Итак, согласно ст.11 Конституции, государственная власть реализуется Президентом, Федеральным 
Собранием, Правительством и судами Российской Федерации. Очевидно, что такое простое перечисление указывает на то, что властей в нашей стране больше трех, известных всему миру. Причем, как следует из текста ст. 94, Федеральное Собрание - парламент - является представительным и законодательным органом, а согласно ч.1 ст.110, исполнительная власть осуществляется Правительством. Каково же место Президента в этой конструкции и как происходит легитимация отдельных ветвей власти в РФ? Согласно ч. 1 ст. 80 Президент в РФ является главой государства. Что это все значит? Согласно позиции Конституционного Суда: «... оставаясь вне пределов традиционно вычленяемых трех ветвей единой государственной власти - законодательной, исполнительной, судебной - Президент интегрирует российскую государственность и, будучи наделен Конституцией значительными нормотворческими полномочиями, контролируя исполнительную власть и выполняя некоторые квазисудебные функции в качестве арбитра в спорах между органами государственной власти, он юридически и фактически «присутствует» во всех властях, определяет эффективность и действенность всех институтов государственной власти в РФ». [16]

Для того чтобы обеспечить беспрецедентные возможности в мировой истории для российского президента, он наделяется всеобъемлющими кадровыми полномочиями в сфере формирования Правительства, Администрации Президента, федерального корпуса судей и руководства высших судов, руководителей исполнительной власти субъектов РФ, прокуратуры, следственного комитета, Центрального Банка и многих других экономических структур. Он также производит ключевые назначения в системах обороны и безопасности, правоохранительных органов. Кроме того, Президент имеет право председательствовать на заседаниях Правительства (ст. 83), а по совокупности конституционных полномочий фактически осуществлять руководство Правительством. При этом в Конституции нет прямой характеристики Правительства как высшей исполнительной власти в стране во главе с Председателем Правительства (ст. 10, 11,110 - 117). Председатель Правительства всего лишь определяет основные направления деятельности и организует его работу (ст.113), но при этом нет даже формулы, что Председатель руководит Правительством. Определение же основных направлений внутренней и внешней политики государства - опять-таки конституционное полномочие Президента (ч.3 ст. 80). Данное полномочие он реализует через Послания ветвям власти РФ, через подписание/ неподписание законов, принятых Федеральным Собранием, через издание указов и распоряжений.

Для еще большей «координации» и «интеграции» всех ветвей власти Президент, помимо правового и кадрового влияния, обладает и так называемым политическим резервом - правом роспуска Государственной Думы (нижней палаты Федерального Собрания, единственного органа государственной власти в РФ, который формально независим от Президента) в случае её непослушания, а также правом немотивированной отставки Правительства и глав субъектов федерации. Получается, что в нашей стране по объему своих полномочий Президент является царем, которого мы выбираем раз в 6 лет.

Как в этой связи выглядит ситуация с Федеральным Собранием РФ? Согласно ст. 94 Конституции оно является парламентом РФ, т.е. представительным и законодательным органом. Единственным, по существу, конституционным средством обеспечения выполнения Федеральным Собранием функции представительства интересов многонационального народа России и выражения его воли в виде закона, являются порядок его избрания, а также контрольные функции парламента. Поскольку парламент в РФ является двухпалатным, то Конституция предусматривает, что Государственная Дума состоит из 450 депутатов, которые выбираются сроком на 5 лет, а Совет Федерации формируется из представителей субъектов Федерации (по одному от представительного и исполнительного органов государственной власти субъекта).

По сути дела, принципиальный вопрос, а именно конкретный порядок формирования палат Федерального Собрания отдан во власть политической конъюнктуры. Что, собственно говоря, и показали дальнейшие события. Порядок формирования палат российского парламента многократно пересматривался, пока не была выстроена так называемая «вертикаль власти», которая, по сути дела, упразднила разделение властей в нашей стране. Так, например, порядок формирования Совета Федерации пересматривался уже пять раз. Сначала его члены выбирались, затем в него входили по должности губернаторы и руководители законодательных собраний субъектов Федерации, теперь входят представители субъекта Федерации, по одному от исполнительной и законодательной властей, также вводился и отменялся ценз оседлости и т.д. С порядком формирования нижней палаты Федерального Собрания - Государственной думой дело обстоит несколько иначе. Поскольку ст. 96 прямо указывает на 
DOI: $10.7256 / 1811-9018.2015 .9 .14210$

При цитировании этой статьи сноска на доі обязательна

\section{Право и политика 9 (189) $\bullet 2015$}

то, что Государственная Дума избирается на пять лет, то получается, что часть 1 этой статьи устанавливает важный принцип её функционирования - периодическое обновление её состава. Ведь формируя представительные органы, граждане реализуют право на участие в управлении делами государства. Но способ выборов депутатов Государственной Думы прямо не установлен Конституцией, что и позволяет власти самостоятельно определять его. Как откровенно отметил Конституционный Суд РФ в Определении от 20.11.1995 № 77-О: «Выбор того или иного варианта и его закрепление в избирательном законе зависит от конкретных социально-политических условий и является вопросом политической целесообразности». Депутаты Государственной Думы четырех созывов (1993-1995 гг., 1995-1999 гг., 1999-2003 гг., 2003-2007 гг.) избирались по смешанной системе: 225 депутатов - по одномандатным избирательным округам, образуемых в субъектах РФ (это так называемая мажоритарная система); другие 225 депутатов - по федеральному избирательному округу пропорционально числу голосов, поданных за федеральные списки кандидатов в депутаты, выдвинутые избирательными объединениями или блоками (это пропорциональная система). На выборах в 2011 году, депутаты избирались только по федеральному избирательному округу пропорционально числу голосов, поданных за федеральные списки кандидатов в депутаты Государственной Думы. В настоящее время вернулись к смешанной системе выборов депутатов нижней палаты. Кроме того, проблема контроля представительной (законодательной) власти за исполнительной властью в российской Конституции остается нерешенной, поскольку она не предусматривает ответственности министров перед парламентом. Тем самым общий баланс властей серьезно деформирован в пользу полномочий Президента и всей исполнительной власти, которую он формирует и полностью контролирует.

В этой ситуации решающую роль могла бы сыграть третья - судебная - власть. В нашей стране, согласно ст. 118 Конституции, правосудие осуществляется только судом. Причем «отправление правосудия является особым видом осуществления государственной власти.... Применяя общее правовое предписание (норму права) к конкретным обстоятельствам дела, судья даёт собственное толкование нормы, принимает решение в пределах предоставленной ему свободы усмотрения». При такой трактовке правосудия, которая изложена в Постановлении Конституционного Суда РФ от 25.01.2001 г. №1-П, роль личности судьи оказывается критически важной для функционирования демократической системы. Именно поэтому, наверное, назначение руководителей высших судов, их заместителей является кадровым ресурсом Президента, а представительный орган только утверждает предложенные кандидатуры. Хотя согласно ст. 120 Конституции, судьи независимы и подчиняются только Конституции и закону, и статус судьи очень высок и хорошо обеспечен, тем не менее, процедура наделения полномочиями не прозрачна и полностью зависит от вертикали власти. Именно поэтому при вынесении решения судья исходит из отождествления интересов народа с позицией исполнительной власти, хотя всем понятно, что интересы власти и народа совпадают только тогда, когда на страну обрушивается большая беда. А в «мирное» время интерес власти состоит в господстве над народом, в ограничении его свободы и игнорировании принципов справедливости. Те же, кто не разделяет «государственную» идеологию, долго не задерживается в рядах судейского корпуса. Только страхом потерять свой высокий материальный и социальный статус можно объяснить поддержку Конституционным Судом и другими судами отмены выборности губернаторов, изменения порядка формирования Федерального Собрания, ликвидации непослушных партий, отстранения от участия в выборах неугодных политиков, фактический запрет властями проведения референдумов, митингов и демонстраций. Это также объясняет, почему наши граждане не верят российским судьям и последней надеждой русских на торжество справедливости остается только Европейский суд по правам человека.

Таким образом, российская Конституция 1993 года и вся практика её реализации до настоящего времени убедительно свидетельствуют о воспроизводстве архетипов русской власти - самодержавия главы государства и дистинкции верховного и подчиненного управления, что не позволяет имплементировать заявленные ценности конституционализма в ткань общественного бытия. Не смотря на провозглашение разделения властей, фактически Президент никому не подконтролен и не от кого не зависит, а правительство, парламент и суды всего лишь содействуют ему в осуществлении исполнительной, законодательной и судебной власти, а не ограничивают его власть. С первой своей стороны, Глава государства - самодержавен, а со второй - осуществляет верховное управление Российской Федерацией. Как известно, легитимность и легальность государственного управления в современном мире зависит от двух вещей. Первое - от способности властвующей элиты создать пространство для 
DOI: $10.7256 / 1811-9018.2015 .9 .14210$

При цитировании этой статьи сноска на dоі обязательна

Антропология права

частной и публичной автономии для всех граждан. И второе, что обязано систематически делать современное государство - это обеспечивать материальные условия для имплементации принципов свободы и справедливости в ткань общественного бытия. Единственным способом добиться этого в современной российской ситуации является конституционализация власти через детальную позитивную имплементацию заявленных ценностей. Только это позволит элиминировать архетипы русской власти.

\section{Библиография:}

1. Гессен В.М. Основы конституционного права. М.: Российская политическая энциклопедия (РОССПЭН), 2010. С. 72.

2. Корф С.А. Русское государственное право. Часть І. СПб., 1915. С. 49-50.

3. Кистяковский Б.А. В защиту права. (Интеллигенция и правосознание)// Вехи; Интеллигенция в России: Сб. ст. 19091910. М.: Молодая гвардия, 1991. С.113.

4. Захаров Н.А. Система русской государственной власти: юридическое исследование. Новочеркасск: Типография Ф. Туникова, 1912. С.115.

5. Захаров Н.А. Система русской государственной власти: юридическое исследование. Новочеркасск: Типография Ф. Туникова, 1912. С.176-177.

6. Казанский П.Е. Власть Всероссийского Императора. М.: Издательство «ФондИВ», 2007. С.47.

7. Коркунов Н.М. Русское государственное право. Т. ІІ. СПб., 1909. С. 7.

8. Коркунов Н.М. Указ и закон. СПб.: Б.И., 1894. С. 257.

9. Захаров Н.А. Система русской государственной власти: юридическое исследование. Новочеркасск: Типография Ф. Туникова, 1912. С.279-280.

10. Захаров Н.А. Система русской государственной власти: юридическое исследование. Новочеркасск: Типография Ф. Туникова, 1912. С.286.

11. Захаров Н.А. Система русской государственной власти: юридическое исследование. Новочеркасск: Типография Ф. Туникова, 1912. С.122.

12. Захаров Н.А. Система русской государственной власти: юридическое исследование. Новочеркасск: Типография Ф. Туникова, 1912. С.303.

13. Гучков А.И. Речи по вопросам государственной обороны и об общей политике. 1908-1917. Пг., 1917. С. 18.

14. Лапаева В.В. Типы правопонимания: правовая теория и практика. М.: Российская академия правосудия, 2012. С. 13.

15. Кутафин О.Е. Российский конституционализм. М.: Норма, 2008. С.7.

16. Комментарий к Конституции РФ. /Под ред. В.Д.Зорькина, Л.В.Лазарева. М.: Эксмо, 2009. С.679.

\section{References (transliterated):}

1. Gessen V.M. Osnovy konstitutsionnogo prava. M.: Rossiiskaya politicheskaya entsiklopediya (ROSSPEN), 2010. S. 72.

2. Korf S.A. Russkoe gosudarstvennoe pravo. Chast' I. SPb., 1915. S. 49-50.

3. Kistyakovskii B.A. V zashchitu prava. (Intelligentsiya i pravosoznanie)// Vekhi; Intelligentsiya v Rossii: Sb. st. 1909-1910. M.: Molodaya gvardiya, 1991. S.113.

4. Zakharov N.A. Sistema russkoi gosudarstvennoi vlasti: yuridicheskoe issledovanie. Novocherkassk: Tipografiya F. Tunikova, 1912. S.115.

5. Zakharov N.A. Sistema russkoi gosudarstvennoi vlasti: yuridicheskoe issledovanie. Novocherkassk: Tipografiya F. Tunikova, 1912. S.176-177.

6. Kazanskii P.E. Vlast' Vserossiiskogo Imperatora. M.: Izdatel'stvo «FondIV», 2007. S.47.

7. Korkunov N.M. Russkoe gosudarstvennoe pravo. T. II. SPb., 1909. S. 7.

8. Korkunov N.M. Ukaz i zakon. SPb.: B.I., 1894. S. 257.

9. Zakharov N.A. Sistema russkoi gosudarstvennoi vlasti: yuridicheskoe issledovanie. Novocherkassk: Tipografiya F. Tunikova, 1912. S.279-280.

10. Zakharov N.A. Sistema russkoi gosudarstvennoi vlasti: yuridicheskoe issledovanie. Novocherkassk: Tipografiya F. Tunikova, 1912. S.286.

11. Zakharov N.A. Sistema russkoi gosudarstvennoi vlasti: yuridicheskoe issledovanie. Novocherkassk: Tipografiya F. Tunikova, 1912. S.122.

12. Zakharov N.A. Sistema russkoi gosudarstvennoi vlasti: yuridicheskoe issledovanie. Novocherkassk: Tipografiya F. Tunikova, 1912. S.303.

13. Guchkov A.I. Rechi po voprosam gosudarstvennoi oborony i ob obshchei politike. 1908-1917. Pg., 1917. S. 18.

14. Lapaeva V.V. Tipy pravoponimaniya: pravovaya teoriya i praktika. M.: Rossiiskaya akademiya pravosudiya, 2012. S. 13.

15. Kutafin O.E. Rossiiskii konstitutsionalizm. M.: Norma, 2008. S.7. 